(2) norden 



\section{Comments on COM (2006) 676 Building a global market}




\section{Comments on COM (2006) 676 Building a global market}

TemaNord 2007:614

(C) Nordic Council of Ministers, Copenhagen 2007

ISBN 978-92-893-1627-9

Print: Ekspressen Tryk \& Kopicenter

Printed on environmentally friendly paper

This publication can be ordered on www.norden.org/order. Other Nordic publications are available at www.norden.org/publications

Printed in Denmark

\section{Nordic Council of Ministers}

Store Strandstræde 18

DK-1255 Copenhagen K

Phone (+45) 33960200

Fax (+45) 33960202

\section{www.norden.org}

\section{Nordic Council}

Store Strandstræde 18

DK-1255 Copenhagen K

Phone (+45) 33960400

Fax (+45) 33111870

\section{Nordic co-operation}

Nordic cooperation is one of the world's most extensive forms of regional collaboration, involving Denmark, Finland, Iceland, Norway, Sweden, and three autonomous areas: the Faroe Islands, Greenland, and Åland.

Nordic cooperation has firm traditions in politics, the economy, and culture. It plays an important rol in European and international collaboration, and aims at creating a strong Nordic community in a strong Europe.

Nordic cooperation seeks to safeguard Nordic and regional interests and principles in the global community. Common Nordic values help the region solidify its position as one of the world's most innovative and competitive. 


\section{Content}

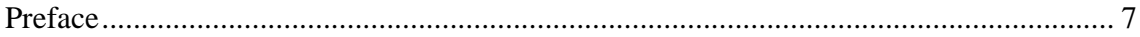

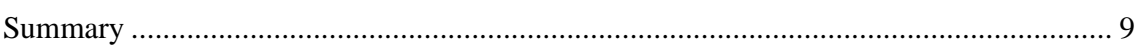

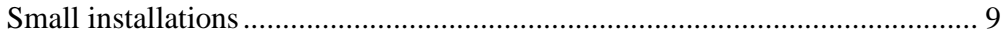

Inclusion of additional sectors and gases ........................................................... 10

Carbon Capture and Storage ................................................................... 11

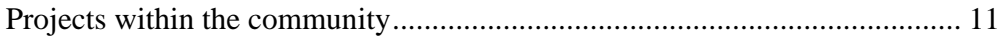

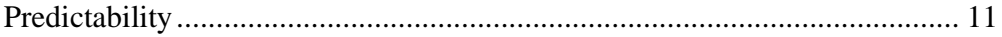

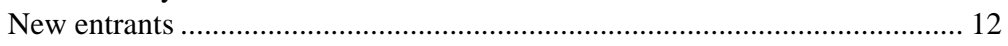

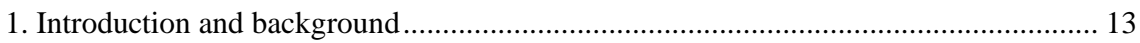

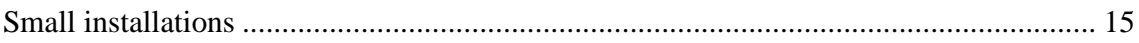

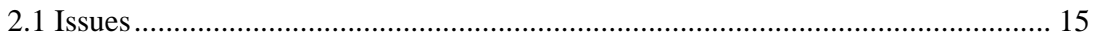

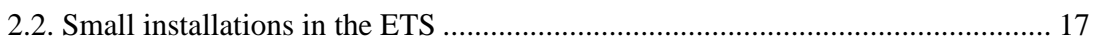

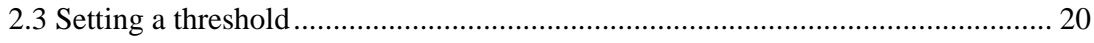

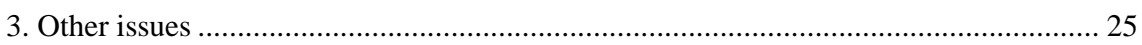

3.1 Other sectors and gases including unilateral inclusion ......................................... 25

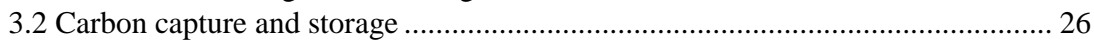

3.3 Projects within the Community .......................................................................... 27

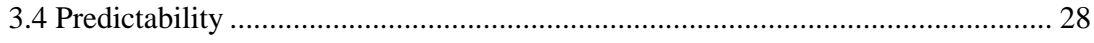

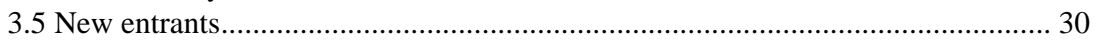

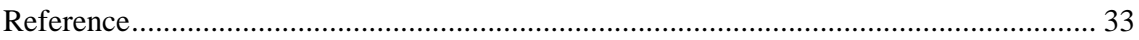

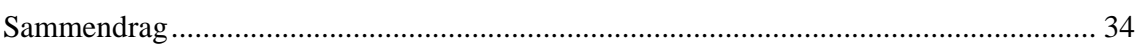





\section{Preface}

In January 2007 ECON was commissioned by the Climate Change Working Group of the Nordic Council of Ministers to conduct an overview analysis of the issues raised in the Annex to the EU Commission communication report "Building a global carbon market - Report pursuant to Article 30 of Directive 2003/87/EC" (COM(2006)676 final)

The Climate Change Policy Working Group does not necessarily share the views and conclusions of the report.

Oslo, June 2007

Jon Dahl Engebretsen

Chairman of the Climate Change Working Group 



\section{Summary}

Directive 2003/87/EC established a scheme for greenhouse gas emission allowance trading, the EU ETS (European Union Emission Trading Scheme). In connection with the review of the Directive, called for in Article 30, the European Commission has published a communication report raising some issues that should be included in the review. This memo contains an overview analysis of these issues. The main focus of this memo is on issues related to the participation of small installations, but several other issues are also discussed.

\section{Small installations}

It is essential that the operating costs of the EU ETS are justified by the achieved environmental benefits. In order to comply with the ETS, all participating installations incur considerable fixed and variable costs. Given the marginal emissions of small installations, it is questionable if the principle of cost-effectiveness justifies the inclusion of small installations under the current ETS rules.

There are two major types of costs associated with participation in the ETS:

- One-off costs - Costs arising from the opening of a trading account, reporting of historical emission, the installation of a monitoring system and administrative changes in the management and organization

- Recurring costs - Costs arising from the annual monitoring, reporting and verification of emissions, transaction costs of trading and the development of a compliance strategy

Monitoring, reporting and verification requirements seem to cause significant financial and administrative burdens on small installations. These often seem disproportionate to the low volume of emissions from small installations. Although the rules for small installations are already simplified, there seems to be room for improved cost-effectiveness by further simplifications. A rough list of possible areas for further simplifications includes:

- Monitoring plan:

- Simplified calculation based methodologies to determine emissions (in some case more simplified than approach tier 1) 
- Resignation of uncertainty analysis

- Verification process

- Simplified verification methodology

- Simplified risk analysis

- Simplified verification report

It is also possible to exclude small installations from participation by setting a threshold. The threshold may be set according to annual emissions or the capacity of the installation.

On the European level installations with emissions lower than 25000 tonnes $\mathrm{CO}_{2}$ per year accounts for $158 \mathrm{Mt}$ of the total $6335 \mathrm{Mt}$ allocated. Excluding installations with emissions lower than 25,000 tonnes $\mathrm{CO}_{2}$ per year would reduce the number of participants by $54.9 \%$ and the emission coverage by $2.5 \%$. A capacity threshold of $20 \mathrm{MW}$ is currently applied to combustion installations. Increasing the threshold to $50 \mathrm{MW}$ would exclude a large number of installations from the ETS. For Sweden and Denmark 588 and 154 installations, respectively would be excluded, accounting for an estimated 3.1 Mt/a in Sweden and 1.4 Mt/a in Denmark.

It is thus possible to reduce the number of participants in the EU ETS without affecting the volume of emissions covered by the scheme very much. If these installations are excluded from the EU ETS one needs to consider the adequateness of alternative policy measures to limit emissions and realize the potential for emission reductions from these sources. Most such alternatives would also involve costs, e.g. by requiring measurement of emissions.

To get a more explicit picture of the costs and benefits of small installations participation in the ETS we suggest that the following issues be investigated in more detail:

- An evaluation of the absolute emission reduction potential for small installations per sector

- Quantitative analysis of costs related to participation in the ETS and alternative policy instruments

\section{Inclusion of additional sectors and gases}

Generally the inclusion of additional sectors and gases in the EU ETS would improve the cost-effectiveness of the scheme, since additional potentials for emission reductions can be exploited.

One precondition is however effective monitoring, and that inclusion achieves real emission reductions, i.e., beyond business-as-usual. Inclusion of other gases and sectors requires the establishment of a baseline for these sectors and gases. For the benefit of both cost-effectiveness and competition issues, it is important that the inclusion is done according to harmonized rules across member states (MS). 


\section{Carbon Capture and Storage}

Carbon capture and storages (CCS) is potentially an important source for reduction of $\mathrm{CO}_{2}$ emissions. The current allocation rules discriminate between technologies because $\mathrm{CO}_{2}$ emitting technologies receive allowances for free, whereas $\mathrm{CO}_{2}$ free technologies do not. Hence, there is an inherent incentive to build capacity without CCS, receive the free allocation, and then invest in CCS if it is profitable. Technology-specific allocation of allowances - where more is allocated the more is emitted means that the ETS at best only weakly incentivises investments in $\mathrm{CO}_{2}$ free technologies. The problem would not exist if all allowances were auctioned.

The incentives are, however, also affected by a possible support scheme (subsidy) for investment in CCS (in existing as well as new generation capacity). The question is whether it should be possible to get both free quotas and investment subsidies for such projects. Depending on the strictness of the ETS, auctioning may not be sufficient to make investments in CCS profitable.

Investment in CCS may be supported by several different measures and the combining effects of these measures needs to be assessed.

\section{Projects within the community}

As an alternative way of including emission reductions in other sectors and gases (plus projects) the desirability and feasibility of introducing a Community-level approval process for emission reduction projects within the Community may be considered. Such projects must focus on emissions from activities that are not suitable for a system with emission caps, and that have a substantial potential to reduce GHG emissions. Such projects would be carried out by ETS participants, but in sectors outside the ETS. But emissions in these sectors should be addressed by other policy measures, and it the additional emission reduction effect of such projects is doubtful.

If this opportunity is introduced, the same rules as those applying to JI projects could be applied. These rules are complicated and costly, and problems concerning double-counting would have to be addressed. Our initial assessment is this should not be prioritized at this stage.

\section{Predictability}

Market participants and investors regard predictability as one of the most important issues, which is understandable considering the long payback time needed for many investments. The predictability of the ETS is influenced by several factors, including the progress of international climate negotiations, the discussions on long-term EU climate commitment pol- 
icy, the ambition and overall strictness of the EU ETS, the development of abatement costs and the detailed design of the EU ETS.

From the policy perspective uncertainty can be reduced through a stable policy environment. Although a flexible approach is needed to incorporate new knowledge, the overall direction of the policy should be predictable. From this perspective, policies, including allocation rules, should also be designed so that they create correct incentives for investments, and so that the incentives are not distorted by short-term interest group pressure.

Long-term EU goals can increase the predictability at the highest level and different designs of the system have different implications for predictability. Auctioning is likely to reduce the political risk, while at the same time increase the financial risk of emitters. Benchmarking has many attractive features compared to grandfathering, but it does probably not reduce the political risk of the system. The tight time schedules seen so far is also a factor reducing predictability.

Compliance periods of roughly the current length, combined with long term planning goals, are probably the preferred feasible option. Too short compliance periods may create price differences over time and induce too much price volatility. An increased scope for banking would mitigate this problem, but borrowing could reduce the environmental effectiveness and the credibility of the system. Too long compliance periods may have the same effect.

\section{New entrants}

Currently there are reserves set a side for new entrants (NER). This is justified since less favourable allocations to new entrants create a bias in favour of keeping old installations and delaying new investments. With auctioning of allowances there would be no need for an NER

Furthermore, it is important that the allocation to new installations is clear, which may mean that the NER should be expanded if depleted. A common NER for the EU with uniform rules for allocation could ensure more efficient investments and reduce the regulatory uncertainty. Generally, allocations should not be technology-specific. 


\section{Introduction and background}

The task at hand is to conduct an overview analysis of the issues raised in the Annex to the EU Commission communication report "Building a global carbon market - Report pursuant to Article 30 of Directive 2003/87/EC” (COM(2006)676 final), hereafter referred to as the COM report.

The COM report reviews issues in Article 30 of Directive 2003/87/EC which established a scheme for greenhouse gas (GHG) emission allowances trading within the EU, hereafter referred to as the Directive and the EU ETS respectively. Article 30 of the Directive provides for the Commission to draw up a report on the application of the Directive, accompanied by proposals as appropriate.

The Annex to the COM report outlines the terms of reference of a Working group which is to review the Directive under the European Climate Change Programme II. The purpose of the Working group is to advise the Commission services on the review of the EU ETS that will lead to amendments to the Directive being proposed in 2007.

In this memo, special focus should is lent to the issues regarding the participation of small installations in the Emission Trading Scheme (ETS). The consequences of simplifying the participation of small installations or completely exempting them from the ETS are discussed based on the COM report. The analysis gives an overview, but even contains some quantification of the effects on the ETS sectors in the Nordic countries.

In addition, the following issues are discussed:

- Other sectors and gases including unilateral inclusion

- Carbon capture and storage

- Projects within the Community

- Predictability

- New entrants

- Monitoring and verification, particularly regarding small installations

The analysis has a Nordic focus throughout, and seeks to emphasize the most important consequences of different proposals. 


\section{Small installations}

\subsection{Issues}

It is essential that the operating costs of the EU ETS are justified by the achieved environmental benefits. Given the marginal emissions of small installations, it is questionable if the principle of cost-effectiveness does also account for small installations under the current ETS rules. In order to comply with the ETS, all participating installations incur considerable fixed and variable costs. Generally, if these costs are too high in relation to the emission reduction potential, the overall purpose of the ETS to provide operators with an incentive to reduce emissions may be lost.

For small installations, it could be the case that the emission reduction potential is actually too low to justify the cost of participation in the ETS. If so, there is a need to improve the cost-effectiveness of the participation of small installations. Furthermore, a workable threshold of participation has to be defined, taking into account the cost of participating. In defining such a threshold, the costs of participating in relation to the emission reduction potential should be analyzed. Moreover, in case there is sufficient justification for removing certain small installations from the scope of the EU ETS, the cost of addressing emissions from these installations through other policies and measures should be taken into account.

There are two major types of costs associated with participation in the ETS:

- One-off costs - Costs arising from the opening of a trading account, reporting of historical emission, the installation of a monitoring system and administrative changes in the management and organization

- Recurring costs - Costs arising from the annual monitoring, reporting and verification of emissions, transaction costs of trading and the development of a compliance strategy

First of all, monitoring, reporting and verification requirements seem to cause significant financial and administrative burdens to small installations. These may often be considered as disproportionate to the low level of actual emissions caused by small installations. To take account of this the Monitoring and Reporting Guidelines ${ }^{1}$ (MRG) from the EU Commission are already simplified. But there is a remaining potential to simplify

1 EU Commission's final draft of the revised Monitoring and Reporting Guiedelines "Establishing guidelines for the monitoring and reporting of greenhouse gas emissions pursuant to Directive 2003/87/EC of the European Parliament and of the Council”; 31/07/2006 
especially the different methodologies within the monitoring and verification process which can be applied.

Simplified rules could be developed comparable to the Small Scale CDM project methodologies. Generally, the monitoring and reporting principles should be streamlined. Also the MRG should provide more flexibility for adopting appropriate methodologies for individual circumstances.

The following list gives a rough indication of where further simplifications in the monitoring and verification guidelines concerning small installations would be useful:

- Monitoring plan:

- Simplified calculation based methodologies to determine emissions (in some case more simplified than approach tier 1)

- Resignation of uncertainty analysis

- Verification process

- Simplified verification methodology

- Simplified risk analysis

- Simplified verification report

Small installations furthermore face costs related to finding an appropriate compliance strategy. Generally, there is a need in assessing the own reduction potential and its marginal abatement costs, to develop a compliance strategy, to understand the market and to update price and market information. In many cases small installations face a lack of management time for these activities. These types of costs will decrease over time. However, there will always be a risk of non-compliance which requires some time to be spent on the development of a compliance strategy.

For small installations relatively high transaction costs regarding the actual trade of allowances build a barrier to participate in the market and actually trade. Automatically the actual incentive to reduce emissions decreases as well. Furthermore, generous allocation of free allowances reduces the incentive to trade and also the incentive to reduce emissions. If emissions are not measured and verified, then the incentive to reduce emissions would also be reduced. Emission reduction efforts result in surplus allowances, but the value of these will be the income from sales minus the cost of trade. Hence, to assess whether it is cost-effective to include small installations in the ETS, the costs have to be seen in relation to the potential emission reduction.

The introduction of a de minimis rule excluding lowest emitters (e.g. below 25.000 tones $\mathrm{CO}_{2}$ per year) from the scope of the ETS has an impact on overall emissions while removing significant administrative burdens from small installations. The question is whether for low emitters alternative policy instruments may realize emission reductions at a more favorable cost/benefit ratio. 


\subsection{Small installations in the ETS}

Figure 1 shows the distribution of installations in the first ETS trading period according to size, and the share of total allocation for each size category. Installations with emissions lower than 25000 tonnes $\mathrm{CO}_{2}$ per year accounts for $158 \mathrm{Mt}$ of the total $6335 \mathrm{Mt}$ allocated. Excluding installations with emissions lower than 25,000 tonnes $\mathrm{CO}_{2}$ per year would reduce the number of participants by $54.9 \%$, and the emission coverage by $2.5 \%$.

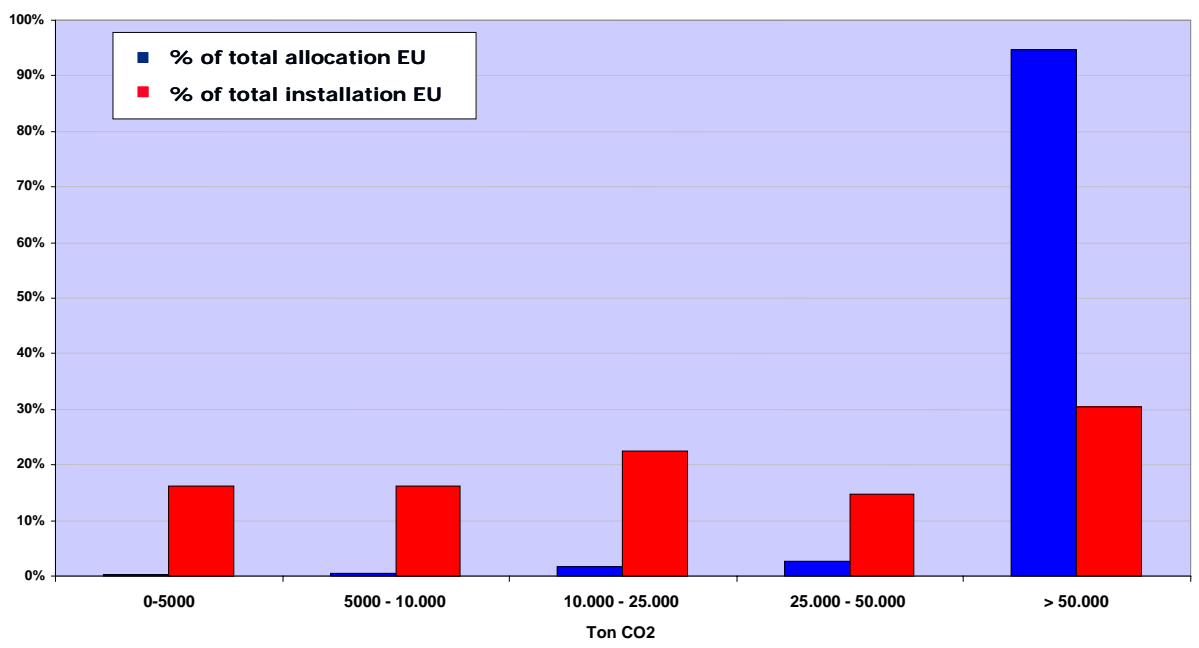

Figure 1 EU ETS allocation according to installation size, first trading period 2005$2007^{2}$

Looking at the Nordic countries (Sweden, Denmark, Norway and Finland), an exemption of all installations smaller than 25000 t. $\mathrm{CO}_{2}$ per year would apply to 1168 installations, or about $75 \%$ of the total number of installations. These installations represent an allocation volume of 14.16 Mt, which account for $4.5 \%$ of the total allocated volume for the four countries in 2005-2007. The following graphs give a more detailed overview of the distribution of installations in the Nordics according to their allocation within the first ETS trading period.

Figure 2 shows the distribution of installations in Denmark. In the first trading period, Denmark's total annual allocation is $33.7 \mathrm{Mt} /$ year on average. The total number of installations is 372 . Installations with emissions lower than 25,000 tones/a constitutes $76 \%$ of the total number of installations and account for $4.7 \%$ of allocated allowances.

2 Source: Ministry of Economic Affairs of the Netherlands 


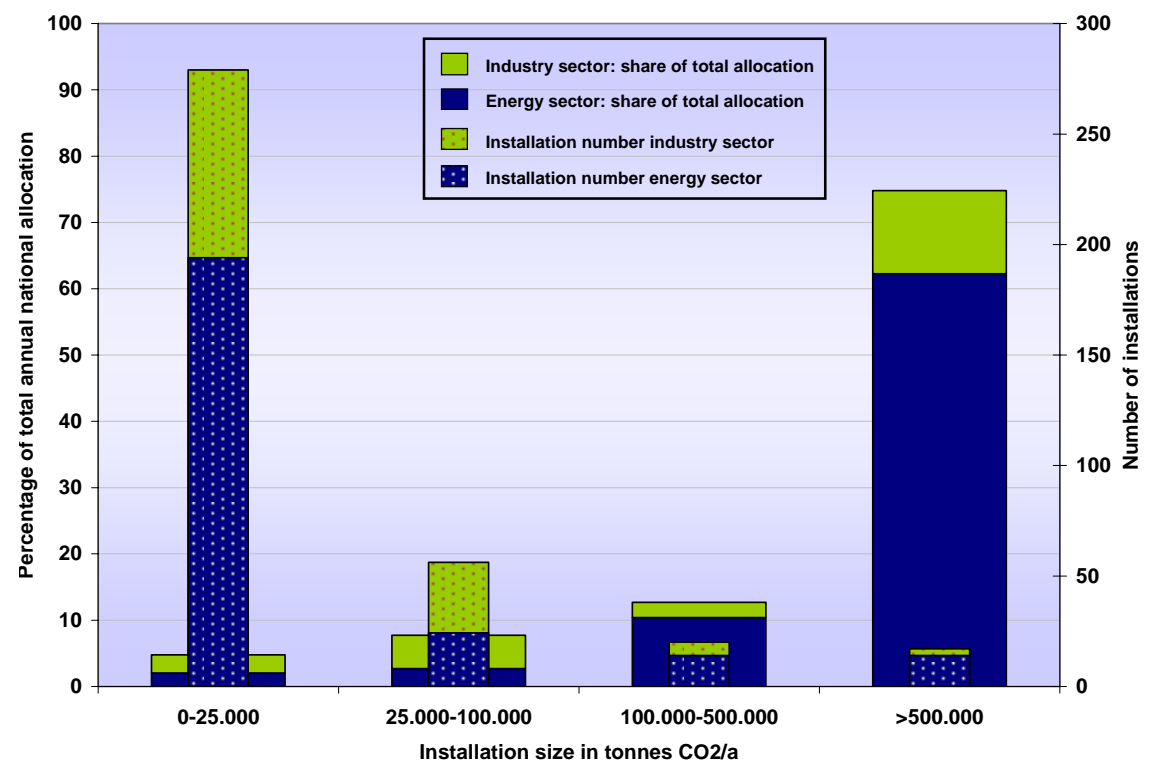

Figure 2 Denmark's allocation by installation size, first trading period

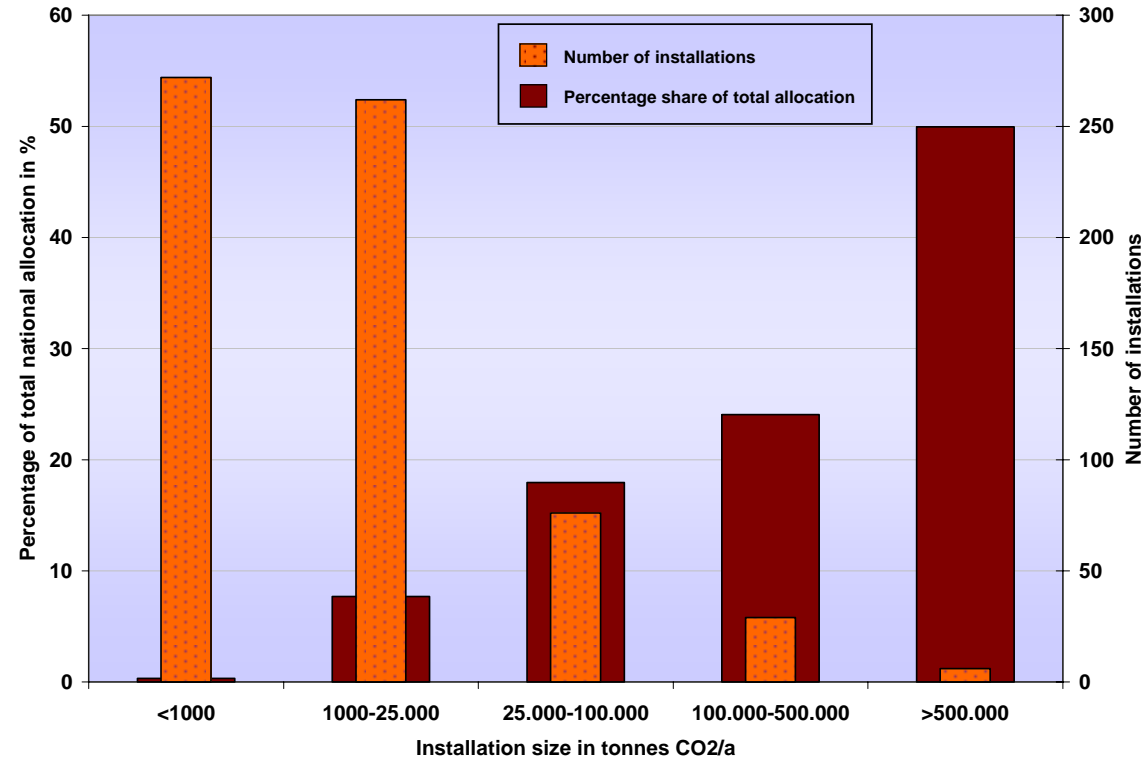

Figure 3 Sweden's allocation by installation size, first trading period

Figure 3 show that Sweden's ETS sector includes approximately 700 installations within the first trading period 2005-2007. These 700 installations have a total annual allocation of $22.9 \mathrm{Mt} /$ year. In its National Allocation Plan, Sweden used the so-called "opt-in rule", which gives the opportunity to unilaterally include installations below the capacity levels 
given in the EU ETS Directive. ${ }^{3}$ According to this, Sweden included small combustion installations if the installation is part of a district heating network, and if the total installed capacity of the network amounts to at least $20 \mathrm{MW} .{ }^{4}$ Hence, installations with emissions lower than 25000 t/a constitute $82 \%$ of the total number of installations and account for $8 \%$ of allocated allowances.

Sweden's second allocation plan includes more installations because of the EUs decision on a harmonized definition of "combustion installation". In the second ETS trading period, all combustion processes, involving industry sectors not covered by the EU ETS, have to be included.5 For Sweden, this means that an additional 35 installations are included in 2008-2012, which causes an additional allocation of $2 \mathrm{Mt} / \mathrm{a}$.

Figure 4 illustrates the Finnish emission trading sector which covers 464 installations in the first trading period. The total number of installations get a total average allocation of $45.2 \mathrm{Mt} / \mathrm{a}$. Also Finland does include small combustion installations, below a rated thermal input of 20 MW, if the combustion installation is part of a district heating network, and if at least one boiler in the network is above 20 MW. In Finland Installations with emissions lower than 25,000 t/a represent $74 \%$ of the total number of installations and account for $3.2 \%$ of allocated allowances.

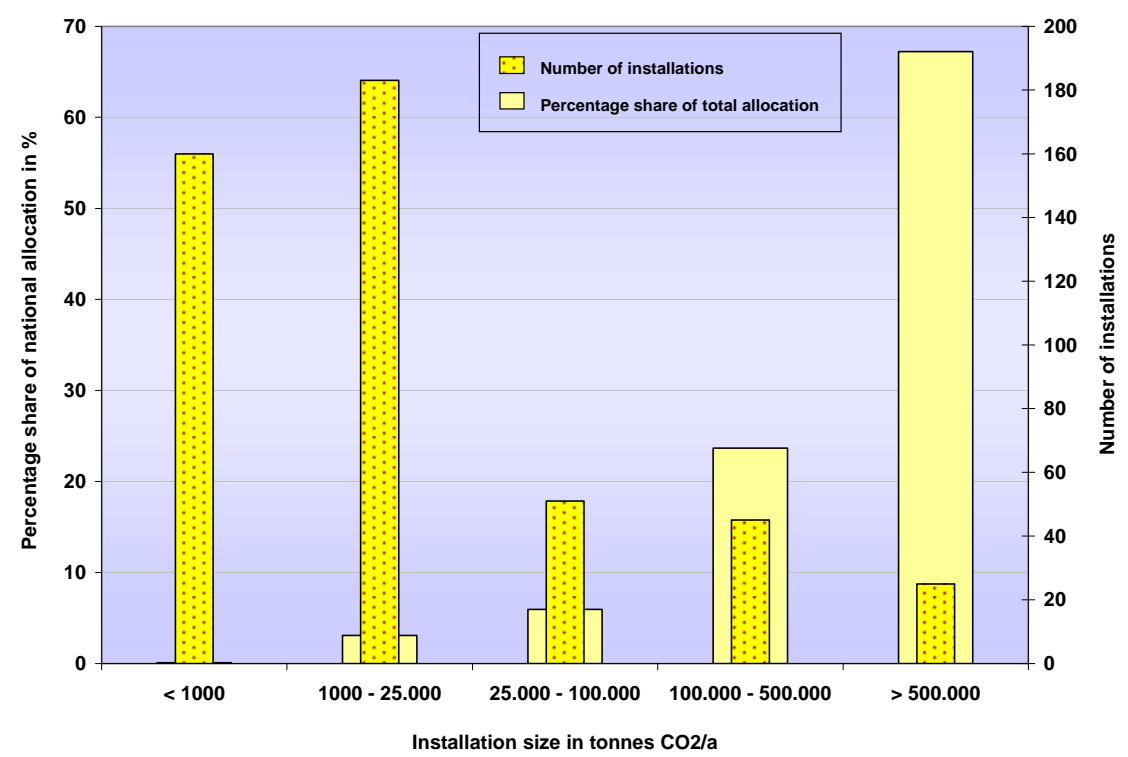

Figure 4 Finland's allocation by installations size, first trading period

\footnotetext{
${ }^{3}$ Article 24 of EU Commission's EU ETS Directive 2003/87/EC

${ }^{4}$ See Sweden's National Allocation Plan 2005-2007; chapter 2.7, page 24

${ }^{5}$ See Communication From the European Commission "Further Guidane on allocation plans for the 2008 to 2012 trading period of the EU ETS", chapter 4.136.
} 


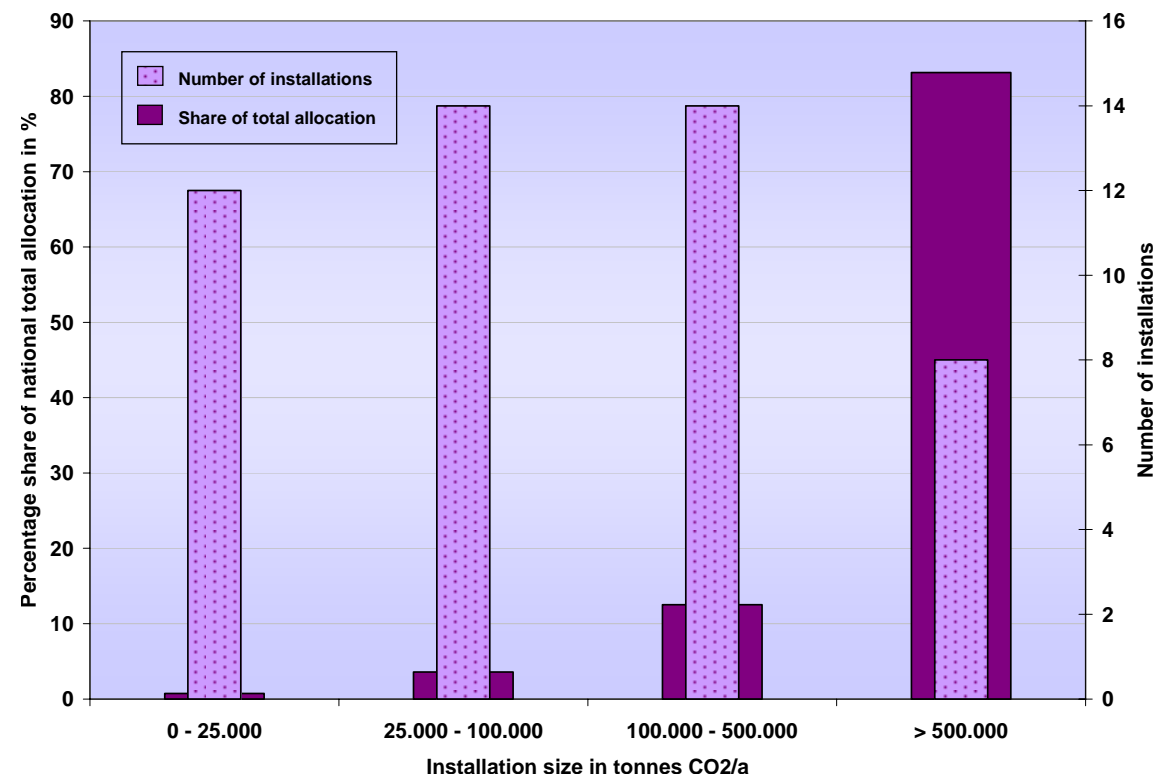

Figure 5 Norway’s allocation by installation size, 2005-2007

In figure 5 Norway's emission trading sector is illustrated. The whole sector gets a total allocation of 20.3 Mt in the whole period 2005-2007. This is shared by 48 installations. In the Norwegian trading scheme, the 12 small installations with annual emissions below 25,000 t/a, constitute $25 \%$ of the total number of installations and account for $0.7 \%$ of the total allocation.

\subsection{Setting a threshold}

There are basically two different measures which can be applied to exclude small installations:

- an emission threshold or

- a capacity threshold

Applying an emission threshold could exclude installations with emissions lower than a certain figure of tonnes $\mathrm{CO}_{2}$ per year. ${ }^{6}$ In the first trading period, excluding installations under 25,000 t/a would reduce the total number of participants strongly (by 54.9\%), while reducing the included emissions by only $2.5 \%$. Setting the threshold at $50000 \mathrm{t} / \mathrm{a}$ would reduce the number of participants by $70 \%$, but still only reduce included emissions by $5 \%$.

\footnotetext{
${ }^{6}$ This approach is used by the EU Commission within its Monitoring and Reporting Guidelines; for installations with emissions lower than $25000 \mathrm{t} \mathrm{CO}_{2}$ per year there may apply simplified monitoring and reporting rules.
} 
Generally, an emission threshold increases uncertainty and still requires monitoring and reporting of emissions although the installation may be excluded from the ETS. Hence monitoring and reporting costs will not disappear. Every installation still has to measure its annual emission levels to prove emissions ex-post, whether the installation is part of the trading scheme or not. In some cases, the uncertainty as to whether an installation will reach the threshold emission level or not may be high. Depending on the alternative scheme which applies to the installation smaller than the threshold, disadvantages or advantages may result for the installation belonging to the one or the other scheme.

A capacity threshold excludes installations according to their size of installed capacity. ${ }^{7}$ Contrary to the emission threshold approach, the effect of shifting the capacity threshold on the number of included plants very much depends on the sector. It could be that capacities of installations in some industry sectors exceed the threshold level anyway. Nevertheless, a capacity threshold would create more certainty on who is in or not, and would not require the same amount of monitoring and reporting as an emission threshold.

In its Emission Trading Directive (2003/87/EC), the EU Commission already applied the approach of a capacity threshold. In Annex 1 of the Directive all categories of activity as well as capacity thresholds of installations covered by the ETS are defined. For example, combustion installations are only covered if the rated thermal input exceeds $20 \mathrm{MW}$. The capacity thresholds for industrial installations refer to production output levels. The installations of ferrous metal production, for example, are included in the ETS if the production capacity exceeds 2.5 tons per hour.

A change in the defined capacity threshold could have a major influence on the number of installations included in the scheme. Assuming that the capacity threshold for combustion installations in the energy sector is increased from $20 \mathrm{MW}$ to $50 \mathrm{MW}$, a lot of installations could be excluded from the ETS. ${ }^{8}$

In Sweden, a potential increase of the capacity threshold for combustion installations in from $20 \mathrm{MW}$ to $50 \mathrm{MW}$ would mean, for the existing trading period, that about 588 installations which represent a total allocated volume of 3,1 Mt/a would be excluded. ${ }^{7}$

In Denmark, the same change of capacity threshold for combustion installations in the energy sector would result in a reduction of the included installation number of 154, representing an allocated volume of 1,4 Mt/a.

The above data are summarized in figure 6 .

\footnotetext{
${ }^{7}$ This approach has been applied by the EU Commission in its EU ETS Directive 2003/87/EC; only combustion installations of a rated thermal input bigger than $20 \mathrm{MW}$ are included within the Scheme.

${ }^{8}$ The calculation is based on the following assumptions: with 4400 h/a baseload hours and a carbon factor of 499,6 g/kWh a $50 \mathrm{MW}$ combustion installation will emitt approximately 100000 ts/a. Hence, in the $50 \mathrm{MW}$ threshold, all combustion installations of the energy sector with less than 100 000 tons/a are included.
} 


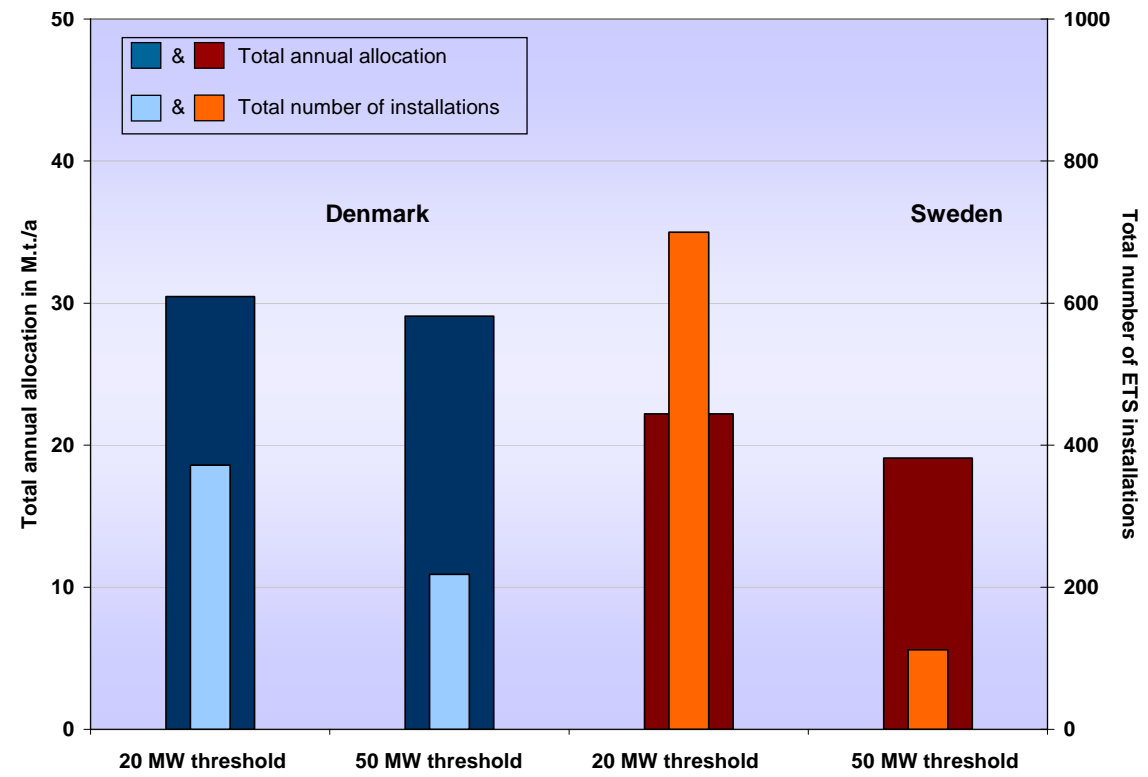

Figure6 Implications of changing Capacity threshold in the ETS first trading period ${ }^{7}$

If small installations are exempt from the ETS, other measures or policies must be implemented. We consider two options:

- A tax on emissions

- Voluntary agreements or standards

Both taxes and voluntary agreements require measuring, reporting and verification of emissions. Standards may not require measuring, but may not be easily implemented in most sectors.

An optimal tax should be in line with the ETS price, and could in principle be adjusted according to the price movements in the ETS market. Such an approach would expose the small installations to the market risk in the assessment of abatement efforts. This would however, probably not be done in an efficient way. If the tax differs from the ETS price, it implies that abatements are not conducted in an efficient manner. If the tax is higher than the ETS price, abatements are potentially carried out in small installations that are more expensive than abatements in installations within the ETS. If the tax is lower than the ETS price, abatements are potentially not carried out in small installations although they are cheaper than abatements in installations within the ETS. A tax may nevertheless represent an efficiency gain compared to participation in the ETS if

- There is a small potential for abatements in small installations and the administrative and transaction costs of a tax is smaller than the administrative and transaction costs of ETS trading (for the relevant installations), or 
- The efficiency loss is smaller than the efficiency loss induced by transaction costs and barriers to trade for small installations in the ETS.

One option could be to make it voluntary for small installations to participate in the ETS or to be subject to a tax. The benefit of choosing a tax would then be the predictability of prices - not having to face the uncertainties contained in the ETS market. The downside would however be to forego the value of free allowances, if a tax applies to all emissions. Alternatively the tax could only apply to emissions exceeding a certain level. This would then reduce the incentives to reduce emissions beyond the defined level (of "free" emissions), but if the abatement potential in small installations is small, this should not represent a high welfare economic cost. (By letting small installations choose between a tax and the ETS, one would think that installations with a high abatement potential would choose the ETS since this would give the opportunity to sell excess allowances.) Perhaps the cost of such freedom of choice is too high?

Alternatively, small installations may enter into voluntary agreements to reduce emissions to a certain level instead of being exposed to a tax. This will not be attractive for small installations with a large abatement potential since they will not reap the benefit of being able to sell excess allowances.

In both alternative options to the ETS small installations would face costs which are related to developing and managing a compliance or reduction strategy. Reduction potentials have to be assessed. Within a trading scheme or a tax system the marginal abatement costs of the reduction measures must be known. Furthermore, the abatement costs would be compared to the market price or the tax, to decide on implementing a technical reduction measure. In a tax system, since the tax level is probably more certain, the risk assessment would be less complex, hence less expensive. In the ETS, due to the high price volatility, the issue of risk is more important and may require detailed and costly analysis.

In conclusion, whatever the regime is, to enhance small installations' emission reductions, one has to measure and report emissions. The main question therefore is what additional costs does the ETS involve that other regimes would not have?

The current Monitoring and Reporting Guidelines of the ETS are very comprehensive and complicated to understand, and probably constitute the heaviest cost burden for small installations. Having read through the Guidelines it seems obvious that there is scope for simplifications in order to make the reporting process easier for small installations. It is however important that the simplifications are not of a type that reduces the incentives for small installations to carry out economically efficient abatement activities. 
Beside the costs for monitoring and reporting, the main costs for small installations seem to be transaction costs and costs associated with the introduction of increased uncertainty. Both transaction costs and uncertainty may be reduced for small installations by using a different political instrument than the ETS. It is however difficult to see how to maintain incentives without measuring and reporting of emissions.

To get a more explicit picture of the costs and benefits of small installations participation in the ETS we suggest that the following issues be investigated in more detail:

- An evaluation of the absolute emission reduction potential for small installations per sector

- Quantitative analysis of costs related to participation in the ETS and alternative policy instruments 


\section{Other issues}

Given the limited scope of the project, some of the other issues mentioned in the COM Report will be briefly - and not exhaustively - commented on in the following section.

\subsection{Other sectors and gases including unilateral inclusion}

In general the trading system should be a more efficient GHG emission abatement instrument the more sectors and gases are included. Even unilateral inclusion of gases and sectors (individual countries defining additional sectors and gases as part of the ETS), should enhance the efficiency of the ETS as an emission reducing instrument.

One precondition is however effective monitoring and that inclusion achieves real reductions, for example beyond business-as-usual. Inclusion of other gases and sectors requires the establishment of a baseline for these sectors and gases. For the benefit of both cost-effectiveness and competition issues, it is important that the inclusion is done according to harmonized rules across member states (MS).

Including additional gases increases the variety of reduction options, offers additional innovation potentials if innovation lead times are respected, and increases liquidity and ultimately the efficiency of the market. As the different GHGs exhibit different monitoring costs, some gases may however be more easily included than others.

It should also be observed that unilateral inclusion could imply that abatements and reduction in the production level within a sector across Europe is not carried out in a cost-efficient manner. Such inclusion would affect the relative competitiveness of the installations in the sector in the countries where it is included in the ETS vs. installations in countries where it is not included. On the other hand, inclusion could be a competitive advantage if the cost of participation in the ETS is lower than the cost of non-inclusion, depending on what policies and measures inclusion in the ETS replace.

As we understand the COM Report, the Commission recommends that new sectors and gases are introduced in 2013. This seems reasonable: the possibility of inclusion of additional gases and sectors during a trading period introduces additional market uncertainties, and increases transaction costs for ETS participants. It also increases the risk of postponing the maturing of the market. For example, there is probably a huge need for market analysis and risk management tools. Developing such tools and gathering data, e.g. on abatement potentials and costs, as well as assess- 
ing the market balance, would be made unnecessary complicated and may be excessively costly under the "threat" of new gases and sectors possibly being introduced within a trading period. This underlines the importance of harmonized rules regarding baseline, monitoring, and allocations being defined before unilateral inclusion is allowed.

\subsection{Carbon capture and storage}

The Working Group is to assess to what extent carbon dioxide capture and geological storage (CCS) are to be recognized in the ETS, in view of comparable treatment of low or non- $\mathrm{CO}_{2}$ emitting activities. It is recommended that the Commission outlines the major EU policy choices for CCS and proposes an EU regulatory framework during 2007.

The current allocation rules discriminate between technologies because $\mathrm{CO}_{2}$ emitting technologies receive allowances for free, whereas $\mathrm{CO}_{2}$ free technologies do not. For example, existing plants which invest in CCS will be part of the ETS and have been allocated free allowances which may be sold in the market. Such installations however run the risk of receiving no or much fewer free allowances for the next trading period since they have no (or very low) emissions. Similarly, new plant built with CCS will not be allocated free quotas, in line with wind power and other carbon-free electricity and heat producing capacity. Hence, there is an inherent incentive to build capacity without CCS and then invest in CCS if profitable. Technology-specific allocation of allowances - where more is allocated the more is emitted - means that the ETS at best only weakly incentivises investments in $\mathrm{CO}_{2}$ free technologies. The problem would not exist if all allowances were auctioned.

The incentives are, however, also affected by a possible support scheme (subsidy) for investment in CCS (in existing as well as new generation capacity). The question is whether it should be possible to get both free quotas and investment subsidies for such projects. Depending on the strictness of the ETS, auctioning may not be sufficient to make investments in CCS profitable although. If one country wants to contribute to the development of CCS technology and subsidise investments, it is clear that the required subsidy would be lower if such installations would also receive free allowances. The reduction in the need for extra subsidies comes from both the value of the allowances, which would be sold in the ETS market, but also from the effect of higher electricity prices. $^{9}$

Investment in CCS may be supported by

\footnotetext{
${ }^{9}$ The long term equilibrium electricity market price is determined by the full cost of new plant. The higher the share of free allowances to the long-term marginal power source, the less is the ETS impact on the long-term power price as well.
} 
- Allocation of free allowances from the national NER

- Allocation of free allowances from a common EU NER

- National R\&D support

- Common EU R\&D support

In a situation where free allowances must be taken from the national allowance pool and where common EU R\&D support from the EU is generous, it may be in the investing country's interest to lobby to keep CCS outside of the ETS. Taking the cost of support to other non-emitting technologies (wind, biomass), and the overall investment incentives of the ETS, it is clearly preferable to apply uniform allocation methods across technologies. From a more long-term infant industry perspective, provisions should be made for additional support to technology development such as within CCS.

\subsection{Projects within the Community}

As an alternative way of including emission reductions in other sectors and gases (plus projects), i.e. an alternative to extend the scope of the ETS, the desirability and feasibility of introducing a Community-level approval process for emission reduction projects within the Community may be considered. Such projects must focus on emissions from activities that are not suitable for a system with emission caps, and that have a substantial potential to reduce GHG emissions.

Such projects would be carried out by ETS participants, but in sectors outside the ETS. But emissions in these sectors should be addressed by other policy measures, and should be carried out anyway if a reasonable policy mix is applied. It seems such projects would first and foremost be attractive if there is a substantial discrepancy between the costs of carrying out abatements in the ETS, importing international credits and domestic action in non-ETS sectors.

Including such projects within the Community as eligible for ETS would be the same as introducing a kind of internal JI system. Hence, the same rules as those applying to JI projects could be used. These rules are substantial and costly and problems concerning double-counting would have to be addressed. Our initial assessment is that making provisions for projects within the Community could be a costly process which would give very little in terms of additional abatements or reduced overall cost of abatements, and hence should not be prioritized at this stage. 


\subsection{Predictability}

Among market participants and investors predictability is generally regarded as one of the more important issues. As part of the European Commission's review of the EU ETS a stakeholder survey was conducted under the guidance of McKinsey \& Company (2005). The survey showed that emission trading was already affecting behaviour and that most stakeholders see long-term issues as the most important ones. ${ }^{10}$ The major reason why long-term issues are seen as so important is linked to the importance of predictability. Considering that the provision of incentives for (low emission) investments is one of the most important elements of emissions trading and that investments within the ETS sectors are generally long-lived with a long payback time this focus on long-term issues with predictable and stable framework conditions is not surprising. In spite of the relatively broad consensus on this issue, no clear recommendations can be derived from the stakeholder responses. The views on what changes should be made simply differ between different stakeholders.

The predictability issue can be discussed on several different levels. On the highest level predictability of the emission trading scheme is affected by the development of the international climate regime. This affects the participants in the ETS in several ways. First of all, the strictness and long-term commitments of the international climate regime is likely to affect the overall strictness of the EU climate commitments, and most probably also the strictness and the planning horizon of the ETS. Of course, in principle the EU can choose a strict ETS regime, i.e. an ETS with a low cap, even without an international agreement, but this is less likely. ${ }^{11}$ Secondly, an international agreement affects the possibilities of the ETS participants to utilize the international market. A broad and strict agreement is likely to increase the demand for international credits, but also increases the possibilities to link the European system to other systems. Thirdly, the competitiveness of the European industry is affected by an international agreement since that will impose similar costs on the industries in other regions. Long-term European goals can reduce this uncertainty to some extent, but in addition to this very little can be done unilaterally.

The second level relates to the development in abatement costs. This depends on many different factors, but technological development is probably the most important long term factor. The extent and timing of technological development is inherently uncertain. Predictability in support schemes for technological development may be beneficial to increase the predictability of the cost developments.

\footnotetext{
${ }^{10}$ Only market intermediaries see short-term issues as the most important.

${ }^{11}$ In the recently proposal from the European Commission on an integrated energy and climate policy this is highlighted by the fact that the stringency of the European climate commitments is suggested to be dependent on reaching an international agreement.
} 
The third level is associated with the actual design of the ETS. Important issues here are allocation methods and rules. So far grandfathering has been used to a large extent. The rules for new installations and plant closures have differed among countries. The above mentioned stakeholder review did not provide a sufficient basis to conclude that alternative approaches, e.g., benchmarking or auctioning, would be less controversial.

Although it is probably correct that alternative approaches would be no less controversial, they may nevertheless increase the predictability of the system. This is particularly true for auctioning since this allocation method will make most of the special provisions and rules redundant. The political risk will thus decline. On the other hand, auctioning could increase the financial risk of emitters since they become financially more exposed to the development in the EUA price.

For benchmarking to increase the predictability it is necessary to reach a long-term European agreement on the type of benchmarking. However, one result from the stakeholder review was that practical acceptance of benchmarking will depend on the adopted implementation. In addition to having a European benchmarking scale, it was for instance mentioned that a sufficient number of correction factors was necessary for acceptance. Although benchmarking has many other benefits relative to grandfathering, it seems highly likely that a benchmarking system will become very complex, and not contribute significantly to reduce the regulatory risk.

Especially for the first trading period the tight time schedule reduced the predictability of the system. The allocations for the second trading period are also delayed. An international agreement for a post-Kyoto agreement is not likely to be reached until 2010 at the earliest, which reduces the predictability regarding the post-Kyoto regime. It seems difficult to reduce the uncertainty pertaining to the international negotiations beyond the current strong signals of continuation of the ETS from the Commission.

Currently the EU ETS is set up with compliance periods, as well as the commitments under the Kyoto Protocol. To achieve cost effective abatement over time the price of emissions should be as stable as possible. ${ }^{12}$ The compliance periods may create price differences over time, but in addition to this too short compliance periods may also induce too much price volatility. This depends on the possibilities of banking (borrowing and saving between periods). With a large scope for banking the price volatility as well as the price differences between periods should be dampened. Saving emission allowances is probably fairly unproblematic. Borrowing from future periods may be much more problematic, particularly if the stability of the future climate regime is being questioned. Similar problems arise with too long compliance periods, i.e., too long

\footnotetext{
${ }^{12}$ At least to the extent that the timing of the emissions do not affect the climate impact.
} 
compliance periods may jeopardize compliance since actions may be delayed, especially if the long term credibility is put into questioning. Compliance period of roughly the current length, combined with long term planning goals is probably the preferred feasible option.

To sum up: Uncertainty is an inherent part of business and every-day life. For long-term investments, research \& development and similar issues with a long pay back time climate change will add to these risks. This is unavoidable. From the policy perspective the uncertainty can be reduced through a stable policy environment. Although a flexible approach is needed to incorporate new knowledge, the overall direction of the policy should be predictable. From this perspective, policies, including allocation rules, should also be designed so that they create correct incentives for investments, and that these incentives are not distorted by short-term interest group pressure.

\subsection{New entrants}

In the first trading period, all MS have chosen to set aside a reserve of allowances to be allocated to new entrants, the so-called New Entrant Reserve (NER). The size of the reserve and the allocation rules vary widely among MS. In its revision of the Directive, the Working group will explore harmonised approaches to new entrants with a view to strengthen incentives for investments in low emitting technologies and ensure comparable conditions for competition across EU. Issues to be considered are:

- Is it suitable to not create an NER for all or some sectors? (To be taken into account: temporary status of NE, degree of competition from outside EU, and climate policies of competitors)

- Harmonized allocation to all, either by common rules or by creating a common reserve (Longer allocation periods? Need for simplicity?

Administrative burden? Incentive effects? Neutrality between different technologies and energy sources?)

- Appropriateness of the definition of NE in the Directive

- Harmonization of provisions for installations that close during a trading period

The most important purpose of emission trading is to ensure that investments are made in low-carbon or carbon-free technologies, i.e. the system should promote long-term efficient investments. This includes both the timing of investment and the choice of technology.

There are two main issues regarding allocations to new entrants 
- To not create unnecessary barriers to entry

- To not discriminate between new entrants (within the same sector)

In long term investment decisions, the full cost of emissions should be taken into account. Allocation of free allowances reduces the total cost of emissions for an investor. If existing installations get more allowances allocated for free than new entrants, it makes it more attractive to keep old installations in production longer and postpone decommissioning. This constitutes a barrier to entry. The net efficiency loss is the difference between the emissions of the old installation and the emissions of a new installation. ${ }^{13}$

Different rules for new entrants in different countries implies a competitive advantage for new entry in the countries with the most attractive allocation rules for new entrants, i.e., share of allowances allocated for free and the length of the allocation period. Using different allocation rules for installations in different sectors should however not imply additional problems.

If the preferred technology for new investments is more or less uniform, the existence of multiple technologies presents a particular problem when it comes to new entry. The electricity sector is the most prominent example of this. There is a wide variety of technologies and fuels available for investments in new electricity generation capacity, including carbon emitting fuels such as coal and gas, and non-carbon emitting technologies such as hydro, wind and nuclear. Since only installations which emit $\mathrm{CO}_{2}$ get allowances allocated for free, the system favours coal and gas installations. The allocation of free allowances in effect constitutes a subsidy to installations which emit $\mathrm{CO}_{2}$. (Compare the choice between a wind mill park and a coal power plant with and without free allowances.) Moreover, if allocations are made according to "need", i.e. expected emissions or a technology-specific benchmark, and there is a uniform share of free allowances, then coal power receives a larger subsidy than gas power. This clearly incentivises the wrong investments in power generation.

The consequence of this is that

- if new installations are to get allowances allocated for free, all installations should get the same amount (not share) of free allowances

- even $\mathrm{CO}_{2}$ free technologies should get free allowances

\footnotetext{
${ }^{13}$ A new installation may have a higher degree of capacity utilization than the old plant. However, via the market mechanism, the production of the new plant never-the-less will replace more or less the same production volume from old plants.
} 
In addition, the allocation of free allowances to new installations caters for a lower long-term price level for electricity, which means a higher consumption level. And to the extent that $\mathrm{CO}_{2}$ free technologies are desired and need investment or production subsidies to be profitable, these subsidies need to be higher.

If the NER proves to be inadequate, i.e. depleted, it means discrimination between early newcomers and old newcomers. This may not be a huge problem from an efficiency point of view, because it would mean that late newcomers would have to buy all their needed allowances in the market, and hence, take all costs into account. Such a provision does however accentuate the incentives to keep old installations, which are eligible to free allocations, for too long instead of investing in new less carbon-intensive installations. Such a provision also introduces an additional uncertainty for investors; Will my installation be registered in time to be eligible for free allowances or not? Even if available allowances are shared between applicants within a certain time period, e.g. a year, the uncertainty remains.

If new entrants are allocated according to the same rules as existing installation, the length of the allocation period does not matter. (Of course this rules out grandfathering or updating as an allocation method, but the Commission has stated that allocations should not be based on historical emissions for any of the installations in the future.)

It is probably very important for new entrants that the allocation of allowances is predictable. This may imply longer allocation periods. Currently, investment decisions must be made on the basis of information about allocations for the second trading period of the ETS, i.e. 20082012. Investors have very little information about allocation rules and the total market balance after 2012. Yet the investments made today will likely produce for a period of 30-50 years ahead. The uncertainty of future climate policies and allocations, clearly introduces additional risks for investors. Additional risks constitute additional costs and tend to postpone investment decisions.

Summing up:

- With auctioning of allowances there would be no need for a NER

- If new entrants get less favourable allocations than existing installations, a bias in favour of keeping old installations and delaying new investments is created

- It is important that the allocation to new installations is clear, which may mean that the NER should be expanded if depleted (e.g. by the government buying EUAs or international credits)

- A common NER for the EU with uniform rules for allocation could ensure more efficient investments and reduce the regulatory uncertainty

- Generally, allocations should not be technology-specific 


\section{Reference}

Directive 2003/87/EC of the European Parliament and of the Council, "establishing a scheme for greenhouse gas emission allowance trading within the Community and amending Council Directive 96/61/EC”, 25/10/2003.

EU Commission communication report "Building a global carbon market Report pursuant to Article 30 of Directive 2003/87/EC” (COM(2006)676 final), Annex.

EU Commission Decision, establishing guidelines for the monitoring and reporting of greenhouse gas emissions pursuant to Directive 2003/87/EC of the European Parliament and of the Council, 29 January 2004.

EU Commission's final draft of the revised Monitoring and Reporting Guiedelines, "Establishing guidelines for the monitoring and reporting of greenhouse gas emissions pursuant to Directive 2003/87/EC of the Euro- pean Parliament and of the Council”;31/07/2006

EU Commission Communication on "Further Guidane on allocation plans for the 2008 to 2012 trading period of the EU ETS”, COM (2003) 830 final.

Danmark's National Allocation Plan 2005-2007; Annex - Liste med danske produktionsenheder, der fra 1. januar 2005 er omfattet af Lov om CO2-kvoter (L 493 af 9. juni 2004)

Finnland's National Allocation Plan 2005-2007, Annex 3 - List of installations and industrial process subject to the Emission Trading Directive.

Ministry of Economic Affairs of the Netherlands, presentation by Paul von Sobbe, 25/08/2005

Sweden's National Allocation Plan 2005-2007; Swedish Environmental Protection Agency, Swedish installation level allocation of EUA 20052007, 25/11/2005 



\section{Sammendrag}

EU-direktivet 2003/87/EC er rammen for handel med drivhusgas emissioner indenfor EU og EØS - European Union Emission Trading Scheme (EU ETS). I forbindelse med en forestående revision af direktivet har Kommissionen i november 2006 publiceret en meddelelse til Det Europæiske Råd, Europaparlamentet m. fl., der behandler nogle områder, der skal indgå i revisionen af direktivet.

\section{Små anlceg}

Det er vigtigt omkostninger ved ETS opvejes af de opnåede miljømæssige gevinster. I forhold til de marginale omkostninger ved at drive små anlæg er det et spørgsmål om princippet om omkostningseffektivitet retfærdiggør inddragelsen af små anlæg under de nuværende ETS regler.

Der er to væsentlige omkostninger forbundet med deltagelse i ETS:

- Startomkostninger - Omkostninger ved oprettelse af en handelskonto, rapportering af historiske emissioner, installeringen af et moniteringssystem og administrative ændringer

- Løbende omkostninger - Omkostninger fra den årlige monitering, rapportering og verificering af emissioner, handelsomkostninger og udvikling af en handelsstrategi

Monitering, rapportering og verificering betyder væsentlige finansielle og administrative byrder for små anlæg, som ofte ikke står i forhold til de lave emissioner fra de små anlæg. Selvom reglerne for små anlæg allerede er forenklet, er der mulighed for forøget omkostningseffektivitet ved yderlige forenklinger. Mulige forenklinger omfatter:

- Moniteringsplan:

- Forenklede beregningsmetoder til at opgøre emissioner med

- Afståelse fra usikkerhedsanalyse

- Verifikation processen

- Forenklet verifikation metode

- Forenklet risikoanalyse

- Forenklet verifikation rapport 
Det er også muligt at udelukke små anlæg fra deltagelse i ETS ud fra en grænse, der kan sættes på grundlag af den årlige emission eller kapaciteten af anlægget.

På europæiske plan står anlæg med emissioner under 25.000 ton $\mathrm{CO}_{2}$ per år for $158 \mathrm{M}$ ton af de i alt $6.335 \mathrm{M}$ ton tildelinger af $\mathrm{CO}_{2}$-kvoter. Udelukkelse af anlæg med emissioner under 25.000 ton $\mathrm{CO}_{2}$ per år vil reducere antallet af deltagere med 54,9\% mes dækningen af emissionen falder med 2,5 \%. For forbrændingsanlæg anvendes i øjeblikket en kapacitetsgrænse på $20 \mathrm{MW}$. Forøgelsen af grænsen til $50 \mathrm{MW}$ vil udelukke et stort antal anlæg fra deltagelse i ETS. For Sverige og Danmark vil henholdsvis 588 og 154 anlæg blive udelukket, dækkende emissioner på anslået henholdsvis 3,1 og 1,4 $\mathrm{M}$ ton $\mathrm{CO}_{2}$ per år.

Det er således muligt at reducere antallet af deltager i EU ETS uden at det påvirker omfanget af emissioner dækket af kvotesystemet særlig meget. Hvis disse anlæg bliver udelukket fra EU ETS er det nødvendigt at se på alternative midler til at begrænse disse emissioner og for at realisere det reduktionspotentiale, der er for disse kilder.

For at få et bedre billede af omkostninger og fordele ved små anlægs deltagelse i ETS foreslår vi, at følgende emner undersøges nærmere:

- en opgørelse af det samlede reduktionspotentiale for små anlæg per sektor

- en kvantitativ analyse af omkostningerne ved deltagelse i

ETS og alternative styringsinstrumenter

\section{Inddragelse af andre sektorer og drivhusgasser}

Inddragelse af andre sektorer og drivhusgasser i EU ETS vil generelt forbedre omkostningseffektiviteten, da yderligere muligheder for emissionsbegrænsninger kan udnyttes.

Det forudsætter imidlertid en effektiv monitering, og at inddragelsen fører til reelle emissions reduktioner. Inddragelse af andre sektorer og drivhusgasser forudsætter etablering af en baseline for disse sektorer og gasser. For at få fordel af både øget omkostningseffektivitet og øget konkurrence er det vigtigt, at inddragelsen sker gennem harmoniserede regler på tværs af landene.

Opsamling og lagring af $\mathrm{CO}_{2}$

Opsamling og lagring af CO2 (CCS, Carbon capture and storages) er en potentiel vigtig metode til at reducere $\mathrm{CO} 2$-emissioner med. De nuværende tildelingsregler forskelsbehandler teknologier, fordi $\mathrm{CO} 2-$ udslippende teknologier modtager frie kvotetildelinger, mens CO2-frie teknologier ikke gør det. Det tilskynder til at bygge anlæg uden CCS, modtage en fri kvotetildeling, og derefter, hvis det er profitabelt, investe- 
re i CCS. Teknologispecifikke tildelinger - hvor jo mere der tildeles jo større er udslippet - betyder at ETS i bedste fald kun svagt tilskynder til investeringer i $\mathrm{CO}_{2}$-frie teknologier. Et problem der ikke ville eksistere, hvis alle tildelinger blev bortauktioneret.

Investeringslysten er også påvirket af forskellige støtteordninger (subsidier) for CCS (i eksisterende så vel som nye anlæg). Spørgsmålet er om det skal være mulig at få frie $\mathrm{CO}_{2}$-kvoter eller investeringsstøtte til CCSprojekter. Afhængig af stramheden af ETS kan bortaktionering være utilstrækkeligt til at gøre investeringer i CCS profitable.

Investeringer i CCS kan understøttes af forskellige regler og den samlede virkning af disse midler bør vurderes.

\section{Lokale projekter}

En alternativ metode at inddrage reduktioner i andre sektorer og af andre drivhusgasser (samt projekter) på er gennem projekter, der lokal arbejder for at nedbringe udslip af drivhusgasser. Disse projekter må fokusere på udslip fra aktiviteter, der ikke passer til et system med emissions loft, og som har et væsentligt potentiale for at reducere udslip af drivhusgasser. Projekterne kunne udføres af deltagere i ETS, men i sektorer udenfor ETS. Men emissioner fra disse sektorer vil kunne mindskes med andre virkemidler, og effekten af sådanne projekter er tvivlsom.

Hvis muligheden bliver indført bør de regler, som bruges ved Joint Implementation projekter, anvendes. Disse regler er komplicerede og bekostelige, og problemer omkring dobbelt tælling skal også håndteres. Det er vores umiddelbare vurdering, at lokale projekter ikke bør printeres på nuværende tidspunkt.

\section{Forudsigelighed}

Markedsaktører og investorer betragter forudsigeligheden af EU ETS som det vigtigste emne, hvilket er forståeligt i betragtning af de lange afskrivningsperioder, der nødvendige for mange af investeringerne. Forudsigeligheden er påvirket af mange faktorer, som forløbet af de internationale klimaforhandlinger, diskussioner af de langsigtede klimaforpligtigelser i EU, ambitionen for og stringensen af EU ETS, udviklingen i afværgeomkostninger og den detaljerede udformning af EU ETS.

Den politiske del af usikkerheden kan reduceres gennem en stabil politik på området. Selvom en fleksibel tilgang er nødvendig for at indarbejde ny viden, bør den overordnede retning af politikken være forudsigelig. I dette perspektiv bør politikker, herunder tildelings regler, være udformet så de skaber et korrekt incitament for investeringer, og så incitament ikke fordrejes af korttids pres fra interessegrupper.

Langsigtede EU mål øger i høj grad forudsigeligheden, mens forskellige udformninger af handelssystemet vil have forskellige påvirkninger af 
forudsigeligheder. Bortaktionering vil reducere den politiske usikkerhed, men på samme tid øge den finansielle usikkerhed. En stram køreplan er også en faktor der reducerer forudsigeligheden.

Handelsperioder af omtrent den nuværende længde, kombineret med langsigtede mål, er sandsynligvis den bedste løsning. For korte handelsperioder kan skabe prisforskelle over tid og for stor prisfølsomhed.

Nye aktører

Der er afsat reserver til nye aktører (NER, new entrants reserve). Det er for at ufordelagtige tildelinger til nye aktører ikke skal skabe en skævhed i forhold til at opretholde gamle anlæg og forsinke nyinvesteringer. Med en aktionering af tildelinger vil der ikke være behov for en NER

Ydermere er det vigtigt, at reglerne for tildelinger til nye anlæg er klare. En fælles NER for EU med ens regler for tildeling kan sikre mere effektive investeringer og mindske den usikkerhed reguleringen giver. Generelt bør tildelinger ikke være teknologispecifikke. 